\title{
An Empirical Analysis on the Influence Factors of the Real Estate Prices in China
}

\author{
Hong-Xia RONG \\ ${ }^{1}$ Harbin University of Commerce, School of Economics, Harbin, China, 150028, \\ ${ }^{2}$ Harbin Finance University, Management department, Harbin, China, 150030, \\ hongxia-2000@163.com
}

Keywords: Real estate prices; Influence factors of the real estate prices; Empirical analysis

\begin{abstract}
The influence factors of prices in the real estate are studied using the panel data of China. By using the theories of econometric and regression model, the article has carried on empirical analysis. The result shows that policy effect is limited to raise interest rates to stabilize the real estate market, and GDP has great impact on real estate prices, but CPI has little impact on real estate prices. Harmonious application of fiscal policy and monetary policy is put forward to regulate the price of real estate, and regulation needs various policy and economic means.
\end{abstract}

\section{Introduction}

With the advancement of mercerization process and the perfect of market economic system gradually, the relationship between the industrial structures under traditional economic system changes greatly. The real estate industry in China gradually has separated from other industries, and become the pillar industry of national economy.

In recent years, the government has taken regulation of the real estate market as an important macro-control measure, especially the limit of the rise in prices. A series of measures have been taken like limiting real estate credit, enhancing the down-payment, cancelling loan preferential interest rates of personal housing and increasing capital ratios of deployment project.

\section{The Equilibrium of Supply and Demand in the Real Estate Market}

Between supply and demand of the real estate exists two states: equilibrium and disequilibrium. Ultimate goal is to achieve the relative equilibrium of real estate market, which the supply and the demand of real estate goods has the same price. Both supply and demand in real estate is a dynamic change, so the disequilibrium of supply and demand are common, and their equilibrium state is relative. In the real economic life, absolute equilibrium is accidental and almost non-existent. There are two states of relative equilibrium: one is that the demand is slightly greater than the supply, the other is that the supply is slightly greater than the demand, the ideal state is the supply is slightly greater than the demand.

Real estate developers should pay more attention to the change of the supply and demand in real estate market, attaching great importance to the condition of its equilibrium state and adjusting business strategy and planning at the micro level. At the macro level, the government should use economic leverage such as tax, interest rates, credit to stimulate or inhibit supply or demand, guiding the curve of supply and demand to move along the residents wants, so as to achieve a new equilibrium.

\section{Empirical Analysis}

\section{The Choice of Data}

\section{Variable Design}

In terms of price, the annual data of sales price of the national commercial housing is collected. 
In terms of the choice of control variables, the changes of macroeconomic will lead to adjustment of supply and demand in real estate, thus affecting the real estate investment and price changes. These external impacts are from supply such as Labor, construction costs, the limit of land development etc., and from the demand such as income, interest rates, etc. In order to better reflect the influence factors of the real estate price, the influence of the supply is joined the CPI variable to control the impact from the supply, GDP variable and the interest rates variable is introduced to control the impact from the demand .Other control variables such as Labor, construction costs, the restriction of land development does not appear in the model, because some variables in the model was not significant, and lack of explanatory power to the model.

Table 1 variable design

\begin{tabular}{c|l}
\hline Variable code & Variable code \\
\hline Fdcjg & Real estate prices \\
\hline Gdp & GDP \\
\hline Jmxfjgzs & urban consumer price index of building and decoration materials \\
\hline $\mathrm{R}$ & The interest rate \\
\hline Spfxsmj & sales area of Commercial housing \\
\hline Czjmrjkzpsr & Urban per capita disposable income \\
\hline E & Error term \\
\hline C & the average of the dependent variable that without the independent \\
& variable on the dependent variable \\
\hline
\end{tabular}

\section{The Data Source}

Considering the development stage in real estate market in China and the variable data availability, this article selects the data of 12 years from 2001 to 2012 as the basis of test. Model data are from China statistical yearbook, the people's bank of China website. The real estate price (RMB), gross domestic product (one hundred million yuan), commodity housing sales area (m2) and urban per capita disposable income (yean) are from the statistical yearbook.

Table 2 2001-2012 sample data

\begin{tabular}{c|c|c|c|c|c|c}
\hline year & Fdcjg & gdp & jmxfjgzs & $\mathrm{r}$ & spfxsmj & czjmrjkzpsr \\
\hline 2001 & $2, \quad 170.00$ & $109,655.17$ & 98.3 & 0.0603 & $22,411.90$ & $6,859.6$ \\
\hline 2002 & $2,250.00$ & $120,332.69$ & 98.5 & 0.0558 & $55,486.22$ & $7,702.8$ \\
\hline 2003 & $2,359.00$ & $135,822.76$ & 99.2 & 0.0558 & $61,857.07$ & $8,472.2$ \\
\hline 2004 & $2,778.00$ & $159,878.34$ & 103.2 & 0.0585 & $77,354.72$ & $9,421.6$ \\
\hline 2005 & $3,167.66$ & $184,937.37$ & 102.6 & 0.0585 & $65,969.83$ & $10,493.0$ \\
\hline 2006 & $3,366.79$ & $216,314.43$ & 103.9 & 0.0612 & $94,755.00$ & $11,759.5$ \\
\hline 2007 & $3,863.90$ & $265,810.31$ & 105.3 & 0.072 & $104,764.65$ & $13,785.8$ \\
\hline 2008 & $3,800.00$ & $314,045.43$ & 106.4 & 0.0729 & $109,366.75$ & $15,780.8$ \\
\hline 2009 & $4,681.00$ & $340,902.81$ & 100.8 & 0.0576 & $111,303.65$ & $17,174.7$ \\
\hline 2010 & $5, \quad 032.00$ & $401,512.80$ & 102.9 & 0.0622 & 27209459 & $19,109.4$ \\
\hline 2011 & $5,357.10$ & $473,104.05$ & 103.9 & 0.0665 & $109,366.75$ & $21,809.8$ \\
\hline 2012 & $5,790.99$ & $519,470.10$ & 101.1 & 0.0615 & $111,303.65$ & $24,564.7$ \\
\hline
\end{tabular}

Data source: China statistical yearbook, the people's bank of China website 


\section{Model Specification}

Due to the real estate tax in China is mainly local tax, which is lack of unified computing and statistical data, so it did not consider the effect of tax policy on real estate price, this article will add the GDP, the consumer price index and interest rate factors in the influencing factors.

Thus we get the following regression model:

$\mathrm{FDCJG}=\mathrm{C}(1)+\mathrm{C}(2) * \mathrm{GDP}+\mathrm{C}(3) * \mathrm{JMXFJGZS}+\mathrm{C}(4) * \mathrm{R}+\mathrm{C}(5) * \mathrm{SPFXSMJ}+\mathrm{C}(6) * \mathrm{CZJMRJKZPSR}$ $+\varepsilon$

\section{Regression Analysis}

The regression results are as follows by using Eviews6.0 econometric analysis software and OLS regression method. In regression results, the whole equation has past the inspection, the affirmative coefficient and the adjusted affirmative coefficient are close to 1, this explains fitting degree of equation is good. But when $\alpha=0.05$, the tests of GDP, SPFXSMJ and t were not significant. Through testing for many times, equation obtains ideal results finally get rid of the GDP, SPFXSMJ.

Table 3 regression results of the model which affect real estate price

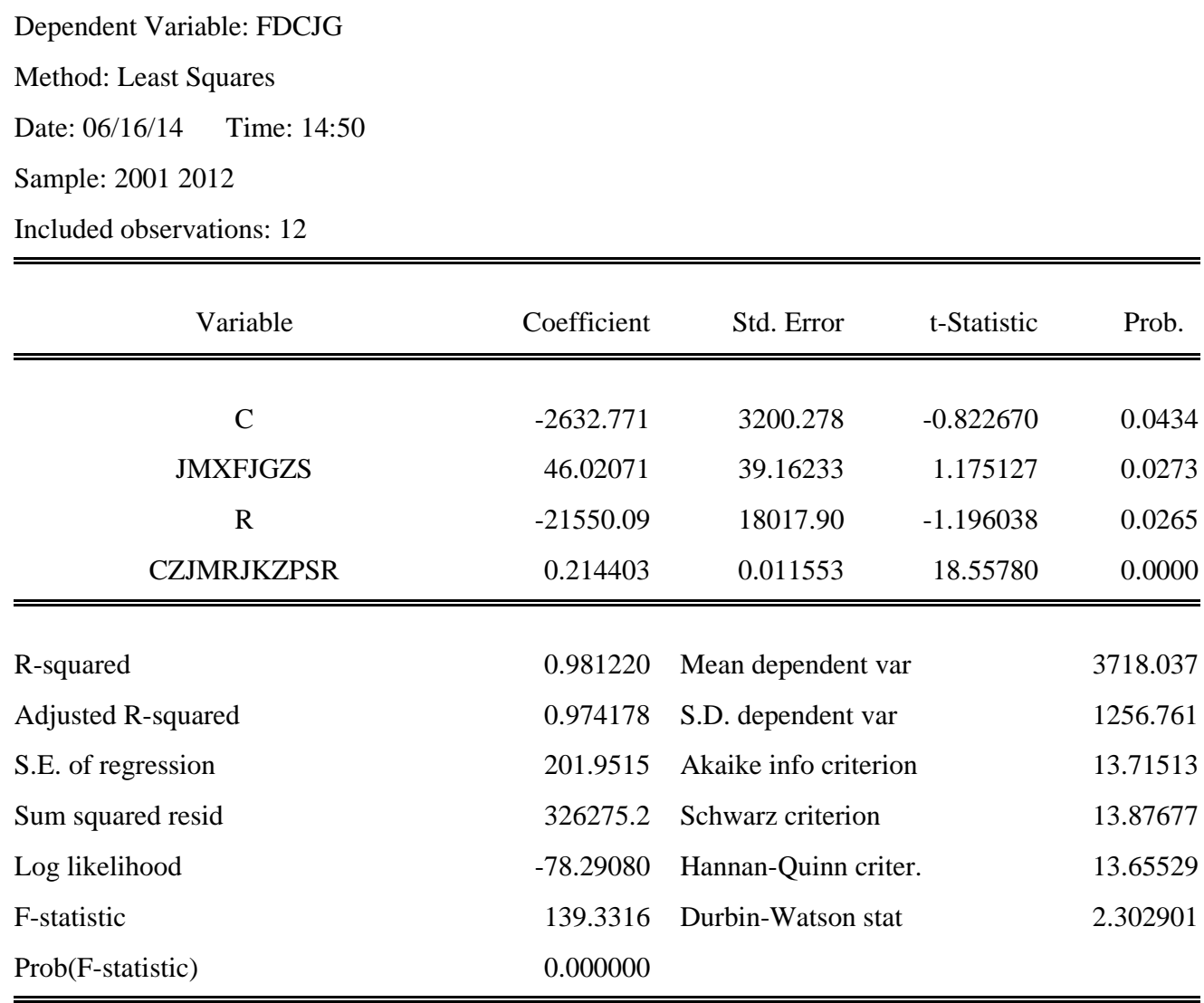

The graphical of dependent variable predictive value is get which is named FDCJG. $\mathrm{FDCJG}=\mathrm{C}(1)+\mathrm{C}(2) * \mathrm{JMXFJGZS}+\mathrm{C}(3) * \mathrm{R}+\mathrm{C}(4) * \mathrm{CZJMRJKZPSR}$

The expression of estimated result of the regression equation is obtained:

FDCJG=-2632.771+46.02071*JMXFJGZS--21550.09*R+0.2144037* ZJMRJKZPSR

\section{Model Test}

Heteroscedasticity Testing

According to the White inspection report, when $\mathrm{P}>0.05$, we cannot deny the original assumption, this shows that the model exists homoscedasticity. 
Table 4 Heteroskedasticity Test: White

\begin{tabular}{llll}
\hline \hline F-statistic & 1.364500 & Prob. F(6, 4) & 0.3983 \\
Obs*R-squared & 7.389595 & Prob. Chi-Square(6) & 0.2863 \\
Scaled explained SS & 1.260938 & Prob. Chi-Square(6) & 0.9738 \\
\hline \hline
\end{tabular}

Test Equation:

Dependent Variable: $\quad \operatorname{RESID}^{\wedge} 2$

Method: Least Squares

Date: 06/21/14 Time: 19: 36

Sample: 20012012

Included observations: 12

\begin{tabular}{lcccc}
\hline \hline \multicolumn{1}{c}{ Variable } & Coefficient & Std. Error & t-Statistic & Prob. \\
\hline \hline C & 439284.3 & 360447.8 & 1.218718 & 0.2899 \\
JMXFJGZS ^2 & $1.24 \mathrm{E}-07$ & $1.52 \mathrm{E}-06$ & 0.081678 & 0.0338 \\
MXFJGZS*R & 6.577482 & 65.33258 & 0.100677 & 0.0241 \\
MXFJGZS* CZJMRJKZPSR & -0.002621 & 0.033367 & -0.078558 & 0.0941 \\
\multicolumn{1}{c}{ R^2 } & $9.05 \mathrm{E}+08$ & $8.65 \mathrm{E}+08$ & 1.046961 & 0.0354 \\
R* CZJMRJKZPSR & -1108302. & 969625.0 & -1.143021 & 0.0416 \\
CZJMRJKZPSR $\wedge 2$ & 294.5558 & 283.8273 & 1.037799 & 0.0358 \\
\hline \hline R-squared & 0.671781 & Mean dependent var & & 36315.25 \\
Adjusted R-squared & 0.179453 & S.D. dependent var & & 30594.24 \\
S.E. of regression & 27713.50 & Akaike info criterion & & 23.55835 \\
Sum squared resid & $3.07 \mathrm{E}+09$ & Schwarz criterion & & 23.81156 \\
Log likelihood & -122.5709 & Hannan-Quinn criter & & 23.39874 \\
F-statistic & 1.364500 & Durbin-Watson stat & & 3.004077 \\
Prob(F-statistic) & 0.398315 & & & \\
\hline \hline
\end{tabular}

(2) Multicollinearity Test: Characteristic Root Method

Table 5 Multicollinearity Test

Null Hypothesis: FDCJG has a unit root

Exogenous: Constant

Lag Length: 1 (Automatic based on SIC, MAXLAG=1)

\begin{tabular}{lccc}
\hline \hline & & t-Statistic & Prob.* \\
\hline \hline Augmented Dickey-Fuller test statistic & & 1.124459 & 0.9932 \\
\hline Test critical values: & $1 \%$ level & -4.420595 & \\
& $5 \%$ level & -3.259808 \\
& $10 \%$ level & -2.771129 \\
& & \\
\hline \hline
\end{tabular}




\begin{tabular}{|c|c|c|c|c|}
\hline \multicolumn{5}{|c|}{$\begin{array}{l}\text { Warning: Probabilities and critical values calculated for } 20 \text { observations } \\
\text { and may not be accurate for a sample size of } 9\end{array}$} \\
\hline \multicolumn{5}{|c|}{ Augmented Dickey-Fuller Test Equation } \\
\hline \multicolumn{5}{|c|}{ Dependent Variable: $\quad$ D(FDCJG) } \\
\hline \multicolumn{5}{|l|}{ Method: Least Squares } \\
\hline \multicolumn{5}{|c|}{ Date: 06/21/14 Time: 20: 22} \\
\hline \multicolumn{5}{|c|}{ Sample (adjusted): 20032011} \\
\hline \multicolumn{5}{|c|}{ Included observations: 9 after adjustments } \\
\hline Variable & Coefficient & Std. Error & t-Statistic & Prob. \\
\hline FDCJG(-1) & 0.120473 & 0.107138 & 1.124459 & 0.3038 \\
\hline D(FDCJG(-1)) & -0.628982 & 0.370252 & -1.698792 & 0.1403 \\
\hline $\mathrm{C}$ & 126.2949 & 337.8855 & 0.373780 & 0.7214 \\
\hline R-squared & 0.330892 & Mean dependent var & & 345.2333 \\
\hline Adjusted R-squared & 0.107856 & S.D. dependent var & & 265.1671 \\
\hline S.E. of regression & 250.4593 & Akaike info criterion & & 14.14567 \\
\hline Sum squared resid & 376379.3 & Schwarz criterion & & 14.21141 \\
\hline Log likelihood & -60.65552 & Hannan-Quinn criter. & & 14.00380 \\
\hline F-statistic & 1.483579 & Durbin-Watson stat & & 2.424111 \\
\hline Prob(F-statistic) & 0.299564 & & & \\
\hline
\end{tabular}

From the test results of unit root we can find that the probability of ADF is 0.993. So we can't refuse FDCJG sequence has an original hypothesis of unit root and can't think the sequence is stationary. We need to precede the difference or co integration analysis for the sequence, according to the same steps for unit root test for sequence $\mathrm{R}$.

Table 6 unit root test

\begin{tabular}{|c|c|c|c|}
\hline variable & ADF & Probability P & conclusion \\
\hline FDCJG & 1.124459 & 0.9932 & non-stationary \\
\hline R & -1.770024 & 0.3717 & non-stationary \\
\hline
\end{tabular}

\section{Conclusion}

Through the above the empirical analysis on the influence factors of real estate price, we can provide reference for the government to make relevant policy to suppress the speculation of real estate market, to stable real estate prices and to control the bubbles of real estate market.

Real estate sales price is not sensitive to interest rates because the current policy of interest rate in China is not flexible. The effect by raising interest rates to stabilize the real estate market is not obvious, and the effect of the policy is limited.

The sustained growth of economic in China will inevitably lead to rising of real estate prices. If coupled with speculation at this time, the bubble of the real estate market would inflate inevitably. A lot of speculative capital is from state-owned enterprises, state-owned banks, and even 
government departments during the real estate superheat. So it is important the reform in the enterprise system and real estate should be accelerated, the real estate investment becomes economic subject of self-sustaining and self-discipline.

Government should give warning and release information on the real estate market, strengthening the education of investors about market risk and stabilizing the market, so as to dissolve the irrational behavior of consumers.

GDP impact on real estate prices is obvious, while the CPI impact on the commercial housing sale price is not obvious.

Fiscal policy should be coordinated with monetary policy. Single fiscal policy and monetary policy is difficult to complete control real estate market, real estate regulation requires various policy and economic means. Aimed at the current situation of $\mathrm{r}$ operation and development of real estate market in China, in the future fiscal policy should be coordinated with monetary policy, in order to formulate and implement reasonable and effective control policy. On the basis of total amount control, monetary policy should be used to adjust the supply and demand of the real estate market, strengthening the coordinate between fiscal policy and monetary policy at the same time.

In terms of controlling housing demand, fiscal policy can adjust it by differential tax policy. For the investment home buyers, the investment housing demand should be adjusted effectively by the means of cash ratio, resource tax and the consumption tax of the special commodity. For the rigid demand for housing groups, more loose fiscal policy and monetary policy should be chosen to meet the needs of the social stability.

\section{Reference:}

[1]Lina, An empirical analysis on the influence factors of the real estate prices in China [D], master's degree thesis of Yunnan university, (2011)

[2]Mashun, A Study on the Financial Policy Promoting the Development of Emerging Strategic Industries [D], master's degree thesis of Ocean university of China,(2012)

[3]liyanyi, dingweidai, Eviews [M], Electronic industry press,(2013) 